\title{
Diversity of bryozoans in a Mediterranean sublittoral cave with bathyal-like conditions: role of dispersal processes and local factors
}

\author{
Jean-Georges Harmelin* \\ Centre d'Océanologie de Marseille, CNRS-UMR DIMAR, Station Marine d'Endoume, F-13007 Marseille, France
}

\begin{abstract}
Saltatory dispersal through stepping-stone habitats is the most plausible model for exchanges of eurythermal species with limited dispersal potential between coastal dark (caves, crevices, etc.) and deep-water habitats. However, direct shoreward advections of propagules from the slope communities may occur, as suggested by the presence of bathyo-abyssal organisms, mainly sponges, in a large shallow-water cave from the French Mediterranean coast characterized by a cold homothermal regime below a within-cave thermocline. Temperature recordings performed year-round in this cave attest that inputs of water parcels uplifted from the slope during upwelling events may advect material right through the cave. In contrast to sponges, bryozoans, another dominant group on cave and deep-water substrates, seem to be unable to benefit from these cross-shelf transfers. Only one presumed stenobathic species from the lower shelf and upper slope, Puellina setiformis, was recorded on the cave walls. The patterns of the spatial distribution of bryozoan species richness (strong negative correlation with distance from cave entrance) and abundance (abrupt decline beyond a topographical change) within the cave's homothermal layer contrast with the success of coexisting sponges. A. 14 mo colonization experiment indicates that settlement rate is dramatically reduced for the whole sessile fauna below the within-cave thermocline. The present results suggest that the successful colonization of the cold homothermal cave by allochthonous larvae is likely to be dependent on rare pulse fluxes and is strongly limited by local abiotic and presumably biotic factors, and that the regional pool of deepwater bryozoans is not a probable source of settlers for onshore aphotic habitats.
\end{abstract}

KEY WORDS: Mediterranean - Bryozoa - Porifera - Dispersal - Cross-shelf transfers - Caves

\section{INTRODUCTION}

Dark submarine caves are very selective habitats from which most coastal species are excluded because of darkness, extreme reduction of water circulation and insufficient food input (Vacelet 1959, Riedl 1966, Cinelli et al. 1977, Harmelin et al, 1985, Laborel \& Zabala et al. 1989, Bianchi \& Morri 1994). Because of progressive hydrodynamic stagnation, this trend is particularly marked in blind caves (Harmelin 1969) where biomass impoverishment and oligotrophy are most acute (Fichez 1990, 1991a, b), approximating levels found in the bathyal zone. These limiting conditions lead to the establishment of a particular sessile com-

•E-mail: jharmel@com.univ-mrs.fr munity (Pérès \& Picard 1964) dominated by sponges, serpulides, bryozoans and foraminiferans, which occupy a limited part of the available space and recruit at a very low rate (Harmelin 1985, Harmelin et al. 1985). Faunal relationships between dark caves and the bathyal zone have been noticed in several taxa, e.g. sponges, scleractinians, serpulids, bryozoans (references in Harmelin et al. 1985). Most of the eurybathic species distributed in both continental slope and nearshore aphotic habitats are also found in cryptic microhabitats scattered over the continental shelf, e.g. rock crevices, undersurfaces of piled boulders, or shells. These microhabitats constitute a network of stepping-stones that presumably allows eurybathic species to spread over a wide depth range despite limited larval dispersal (Harmelin 1986). As most submarine caves along the Mediterranean coast are located 
within the 10 to $20 \mathrm{~m}$ depth range, their submerged phase started during the last Holocene sea-rise, 7000 to 8000 yr ago (Pirazzoli 1991). Although this is relatively recent, enough time has probably elapsed for the present cave communities to be shaped by multiple and diverse colonization events. Until recently, our knowledge of the biotic organization of submarine caves was based on cavities with a temperature regime similar to that observed in the shallow sea or with episodic warmer phases (in karstic caves with an inward ascending profile: Passelaigue \& Bourdillon 1985). These thermal conditions prevent caves of this type from being colonized by strictly deep-water, stenothermal species. A recent census of a Mediterranean nearshore dark cave with abnormally low temperatures (3PP Cave, France) led to the exceptional discovery of true bathyal or bathyo-abyssal organisms, i.e. the hexactinellid Oopsacas minuta, the Cladorhizidae sponge Asbestopluma hypoged, the demosponge Hamacantha implicans, at least 3 other sponges, a tartigrade Coronarctidae, and an unidentified echiurian (Vacelet et al. 1994, Vacelet \& Boury-Esnault 1995 Vacelet 1996, in press, pers. comm., Villora-Moreno 1996). These findings offer evidence that despite the barrier of the thermocline that separates shallower and deeper faunas (Valentine \& Jablonski 1982) shoreward transfers of propagules from bathyal depths are possible under certain hydrological conditions and that coastal aphotic habitats constitute interesting models for supply-side ecology (Roughgarden et al. 1987). Thus, the integration of deep-sea colonists into the cave community addresses the question of the respective role of regional and local processes in the control of richness (Ricklefs 1987, Cornell \& Lawton 1992).

The major goal of this study was to answer to the following questions: (1) What are the circumstances and physical processes that allow propagules from the slope to be transported into littoral aphotic habitats?

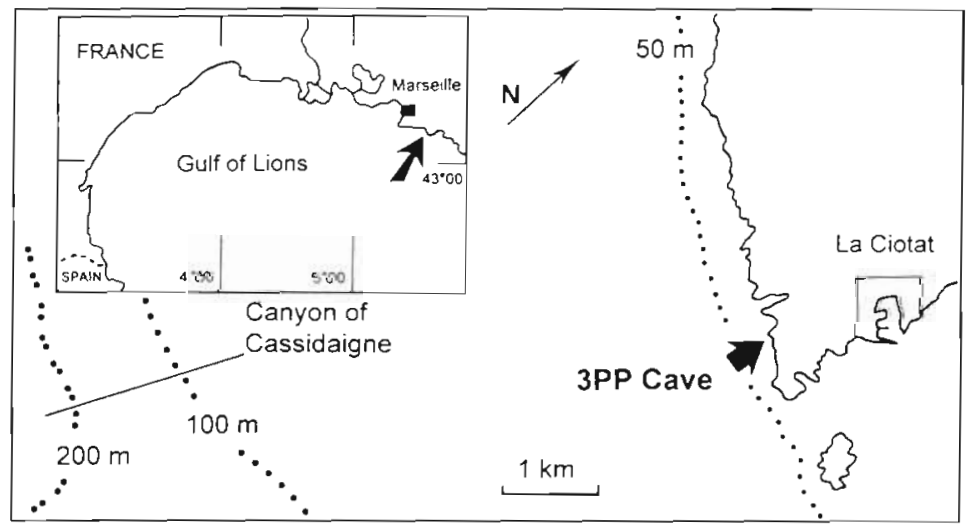

Fig. 1. Location of 3PP Cave and Canyon of Cassidaigne
(2) Does the unusual bipolar distribution (continental slope-nearshore cave) observed among bathyoabyssal sponges also occur among bryozoans? (3) Are sponges and bryozoans equally successful in utilizing the resources of 3PP Cave? (4) Is the flux of propagules particularly intense into this cave?

\section{MATERIAL AND METHODS}

Study site. The study region, extending from Marseille to Toulon on the French Mediterranean coast, is characterized by a narrow continental shelf and steep slope profile intersected by deep canyons (Froget 1974), by very strong wind-induced upwellings (Millot 1979) occurring when the N-NW Mistral wind blows, and by a rocky shore with numerous shallow-water underwater caves, mostly of karstic origin (Bonifay \& Courtin 1980) and thus concentrated along the western, calcareous part of this region (Marseille-Cassis).

The 3PP Cave (for '3-Pépés', i.e. '3-Grandads') is located below the Bec-de-l'Aigle Cape, near La Ciotat (4. $3^{\circ} \mathrm{09} .47^{\prime} \mathrm{N}, 05^{\circ} 35.01^{\prime} \mathrm{E}$ ), only $7 \mathrm{~km}$ from the nearest $200 \mathrm{~m}$ isobath on the abrupt, rocky, eastern side of Cassidaigne Canyon (Fig. 1). This cave is a $-120 \mathrm{~m}$ long, 3 to $7 \mathrm{~m}$ wide, non-karstic, blind tubular cavity running through an Upper Cretaceous conglomerate. Its general shape is rectilinear except for a $30^{\circ}$ change of orientation 45-50 m from the cave entrance (hereinafter, distances from entrance are referred to as $x$ $\mathrm{m} / \mathrm{e}$, i.e. $x$ meters from the entrance). The inner water body measures roughly $3500 \mathrm{~m}^{3}$. Throughout the cave, the floor is covered by thick ( $>1 \mathrm{~m}$ ) muddy deposits. In contrast to karstic caves, which are the most widely studied cave type in the Mediterranean, the floor of 3PP Cave presents an inwardly descending profile (Fig. 2). This topography is responsible for a rare pattern of hydrological stratification, first evidenced by the relative stability of the water temperature around winter values (Vacelet et al. 1994). The cave is roughly divided into 2 chambers (outer: $0-50 \mathrm{~m} / \mathrm{e}$, and inner: $50-120 \mathrm{~m} / \mathrm{e}$ ) on the basis of topographical features (shape of vertical section, roof elevation, floor slope, and orientation). The outer chamber communicates with the open sea by a small, shallow entrance (vault/floor depths: $12 / 15 \mathrm{~m}$; see Fig. 2) and is roughly triangular in section; its height and floor width increase rapidly towards the interior. The roof of this outer chamber slopes inward from $-7 \mathrm{~m}$ at $10 \mathrm{~m} / \mathrm{e}$ to $-18 \mathrm{~m}$ at $45 \mathrm{~m} / \mathrm{e}$, while the floor slopes steeply from $-15 \mathrm{~m}$ at the cave mouth to $-22 \mathrm{~m}$ at $25 \mathrm{~m} / \mathrm{e}$ and reaches $-25 \mathrm{~m}$ at $40 \mathrm{~m} / \mathrm{e}$. On the basis of the 
Fig. 2. Longitudinal section of 3PP Cave; location of the temperature recorders and spatial distribution of the deepwater aliens. A, B, C: cave zones delimited by a thermocline (THd) and a topographic discontinuity (cave bend: TOd)

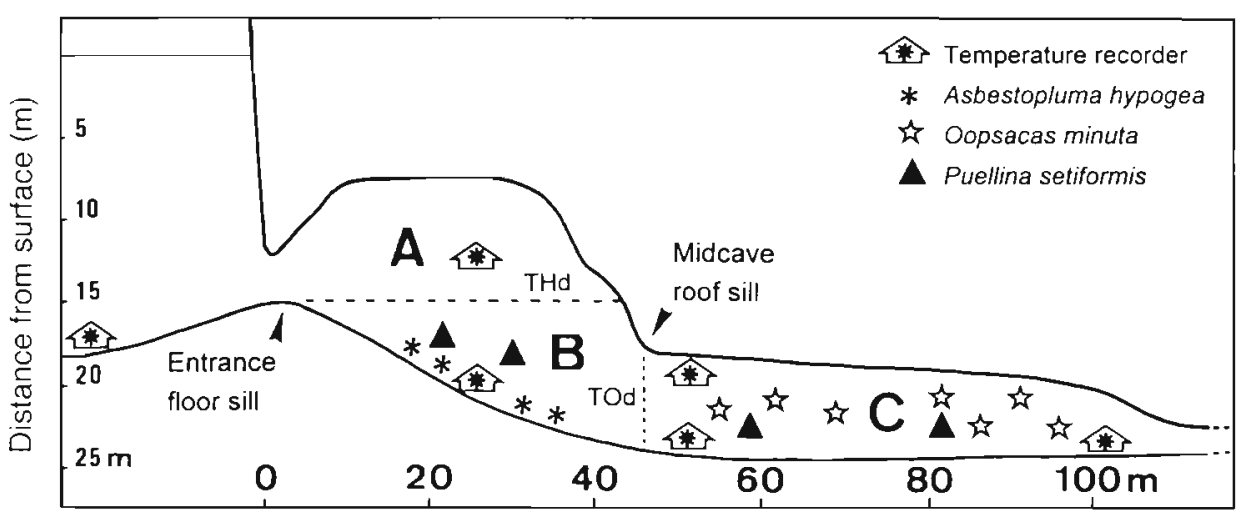

Distance from cave entrance $(\mathrm{m})$ thermal stratification observed in the outer chamber, it has been subdivided into 2 zones $(A<-15 m<B$ ). The inner chamber (C) differs from the outer chamber in its orientation (S-N), section shape (roughly semi-circular) and height (roof: -18 to $-20 \mathrm{~m}$, floor: -24 to $-25 \mathrm{~m}$ ).

Data sampling. In order to infer transport processes from thermal features, temperature was first measured several times each season from 1992 to 1995 with a high-precision digital thermometer and thereafter continuously recorded from April 1995 to July 1996 at significant locations inside and outside 3PP Cave. Six electronic temperature recorders (Deep-Sea Sealoggers, accuracy: $0.16^{\circ} \mathrm{C}$, programmed for 10 measurements $\mathrm{d}^{-1}$ ) were placed outside the cave against a rocky wall ( 1 station: $-18 \mathrm{~m}$ ) and inside the cave at different depths and distances from the entrance $(5$ stations: $25 \mathrm{~m} / \mathrm{e},-13 \mathrm{~m}$ and $-22 \mathrm{~m} ; 50 \mathrm{~m} / \mathrm{e},-18 \mathrm{~m}$ and $-24.5 \mathrm{~m} ; 100 \mathrm{~m} / \mathrm{e},-24 \mathrm{~m}$ ) (Fig. 2). Species were classified into 4 categories (Fig. 3) defined by their vertical distribution in relation to the summer thermocline $(-70$ to $-90 \mathrm{~m}$ in the study region): (1) stenobathic deepwater species (SDW), (2) eurybathic species distributed on both sides of the thermocline but restricted at shallow depth to cryptic aphotic habitats ('cryptobathyal' species: ECB), (3) eurybathic sciaphilous (= shade-loving) generalists (ESG), with broader environmental requirements, (4) stenobathic shallow-water species (SSW), restricted to habitats shallower than the summer thermocline. The SDW species are presumably stenothermal while ECB, ESG and SSW species are eurythermal. A regional pool of potential colonists corresponds to each of these categories. The terms eurybathic and stenobathic are thus used here for benthic organisms living in the neritic zone, i.e. from the shore to the upper slope, while their current use in deep-sea ecology is for classifying abyssal and hadal fauna (Vinogradova 1979). The species composition and structure of the 3PP Cave's actual bryozoan pool were analysed along spatial gradients and compared to the stock of species residing in proximate deep-water habitats, which is considered as a potential regional pool for 3PP Cave colonization. The terms 'regional pool' and 'actual pool' are used as defined by Pärtel et al. (1996): the regional pool is the set of species occurring in a certain region and which are capable of coexisting in the target community', the actual pool is 'the set of species present in the target community' (here, 3PP Cave). Sampling in the 3PP Cave was carried out by SCUBA diving at stations distributed along spatial gradients defined by depth and distance from the entrance. These stations were not precise spots but significant zones measuring several square meters. For easier sample location and safer diving, the distance from entrance was marked out every $10 \mathrm{~m}$ along a longitudinal line stretched along the roof and by transverse lines across the floor. Sessile fauna was collected by breaking prominent portions of walls with a ham-

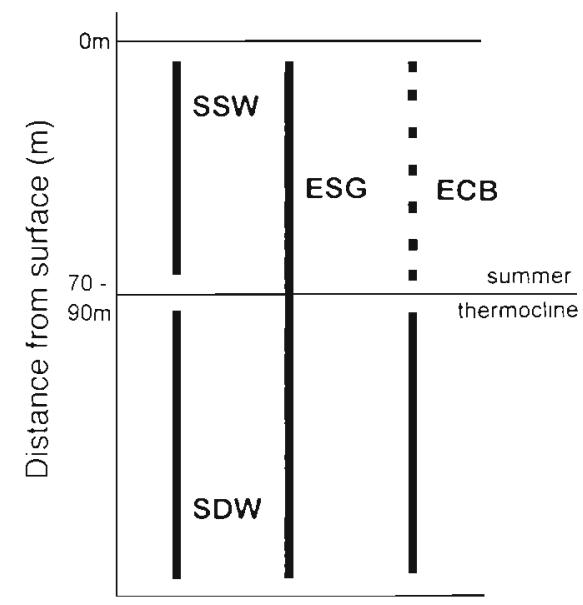

Fig. 3. Depth-range categories of bryozoans in relation to the depth of the summer thermocline in the study region. SSW: stenobathic shallow-water 5pecies; SDW: stenobathic deepwater species; ESG: eurybathic sciaphilous generalists; ECB: eurybathic cryptobathyal species 
Table 1. Features of 7 sampling stations in zones $A, B$ and $C$ of 3PP Cave. For stations, distances from the entrance $(x \mathrm{~m} / \mathrm{e})$ are approximate, with $\pm 2.5 \mathrm{~m}$ in Zones $\mathrm{A}$ and $\mathrm{B}$, and $\pm 5 \mathrm{~m}$ in Zone $C$. The sampled area is the estimated surface of all wall fragments sampled at each station. $n=$ no. of samples

\begin{tabular}{|c|c|c|c|c|c|}
\hline Station & Zone & $x \mathrm{~m} / \mathrm{e}$ & $\begin{array}{l}\text { Depth } \\
(\mathrm{m})\end{array}$ & $n$ & $\begin{array}{l}\text { Sampled area } \\
\qquad\left(\mathrm{cm}^{2}\right)\end{array}$ \\
\hline 1 & A & 12 & $11-14$ & 4 & 1500 \\
\hline 2 & A & 25 & $11-14$ & 4 & 1650 \\
\hline 3 & B & 25 & $18-22$ & 7 & 2525 \\
\hline 4 & B & 40 & $17-22$ & 7 & 3300 \\
\hline 5 & $\mathrm{C}$ & 60 & $19-21$ & 9 & 2775 \\
\hline 6 & C & 80 & $21-23$ & 4 & 2800 \\
\hline 7 & C & 100 & $19-22$ & 10 & 5175 \\
\hline
\end{tabular}

mer and chisel. Consequently, the size of each sample was quite variable, ranging approximately from $100 \mathrm{~cm}^{2}$ to $>1000 \mathrm{~cm}^{2}$. In total, 45 wall samples were collected from 7 stations in Zones A, B and C from March 1991 to October 1995 (Table 1). The relative cover of walls by the dominant sessile groups was estimated from collected wall fragments using a stereomicroscope at low magnification. The average percent cover of sponges and bryozoans at each station along the cave gradient was calculated from 50 to 80 microscopic fields with the aid of a 100 quadrat grid $\left(=1 \mathrm{~cm}^{2}\right.$ field) fitted to a stereomicroscope eyepiece. Data on bryozoans from the lower continental shelf and upper slope of the Gulf of Lions were provided by fauna censuses made by Gautier (1962), Harmelin (1976, unpubl. data) and Zabala et al. (1993). Comparisons with the bryozan assemblages living in dark karstic caves were made using data from Trémies Cave (Harmelin 1969, 1985, unpubl. data), a cavity with extended dark parts, $8 \mathrm{~km}$ away from 3PP Cave. The between-assemblage similarity in species composition was assessed using the Jaccard coefficient of community (Cheetham \& Hazel 1969). Morphometric indications of habitatrelated populational differences were sought among eurybathic bryozoan species. Biometrics of zooids (length of frontal shield in Puellina species, zooid length in other species) were performed on 6 species sampled in 4 habitat types: 3PP Zones $\mathrm{A}$ and $\mathrm{B}+\mathrm{C}$, nearby karstic caves and deep-water bottoms. Measurements were taken at high magnification using a micrometer eyepiece fitted to a stereomicroscope on zooids randomly sampled on 'old' colony portions in order to avoid the progressive size increase occurring in the youngest part of colonies (astogenetic zone). Ten colonies were considered per habitat type and 10 zooids were measured per colony. As sarnples from 3PP Cave were pseudoreplicates (Hurlbert 1984), ANOVA analyses were not allowed for comparing the
4 habitat situations; consequently, the means and standard deviations from these sets of measurements were only plotted. A colonization experiment was initiated in collaboration with J. Rubin, University of Plymouth, UK. Five panels, each composed of eight $15 \times 15 \mathrm{~cm}$ black perspex plates (both faces were available for colonization, one completely, the other partly, giving a total of $375 \mathrm{~cm}^{2}$ per plate) on a PVC frame, were deployed in the cave in July 1995: 2 in Zone A (-13 m: $12 \mathrm{~m} / \mathrm{e}$ and $25 \mathrm{~m} / \mathrm{e}), 2$ in Zone B (-21 $\mathrm{m}: 25 \mathrm{~m} / \mathrm{e}$, lateral and medium position) and 1 in Zone C (-22 m: $50 \mathrm{~m} / \mathrm{e})$. Both panels from Zone A were collected in September 1996 and all bryozoan colonies established on the 2 sets of 8 plates were identified and counted under a stereomicroscope. Panels from Zones B and C were left in the cave and their colonization was examined in situ using a $\times 3.5$ magnifying lense and a powerful light. This technique was sufficient for verifying the lack of macroscopic colonizers on most plates and for identifying 2 easily recognizable species which were the only bryozoans settling on $B$ and $C$ panels.

\section{RESULTS}

\section{Thermal regime and water import in $3 P P$ cave}

As the cave communicates with the open sea by a single entrance, all water and particle exchanges are funneled through the upper part ( $<15 \mathrm{~m}$ depth) of the outer chamber (Zone A). Because of the raised position of the floor at the cave mouth ( $3 \mathrm{~m}$ above the inner roof sill and $10 \mathrm{~m}$ above the cave floor; Fig. 2), cold water is density-trapped inside in the lower half of the outer chamber (Zone B) and in the whole inner chamber (Zone C). As a result, the huge water body $\left(>2500 \mathrm{~m}^{3}\right.$ ) filling the cave below the depth level of the entrance sill (Zones B and C) remains nearly homothermal all the year round. Between 1992 and 1996, temperature fluctuated yearly from 12.8 to $14.5^{\circ} \mathrm{C}$. In contrast, the temperature fluctations in Zone A were similar to that in the open sea (Fig. 4). Water stratification between Zone A and Zone B was particularly marked during the warm season when the weather conditions were steady. The maximum temperature difference was observed in late summer, e.g. $\Delta t=11^{\circ} \mathrm{C}$ across the $\mathrm{A} / \mathrm{B}$ thermocline in August 1995. Therefore, the lower water body is periodically sequestered within the cave, and its renewal depends mainly on the reversal of the density ratio at the $\mathrm{A} / \mathrm{B}$ thermal front, i.e. on outside temperature cooling. Cases of destratification generating downwellings and horizontal transfers within the cave were evidenced by temperature recordings (Figs. 5 \& 6). Downwellings induced by destratification occurred at the begining of the cold season when the 


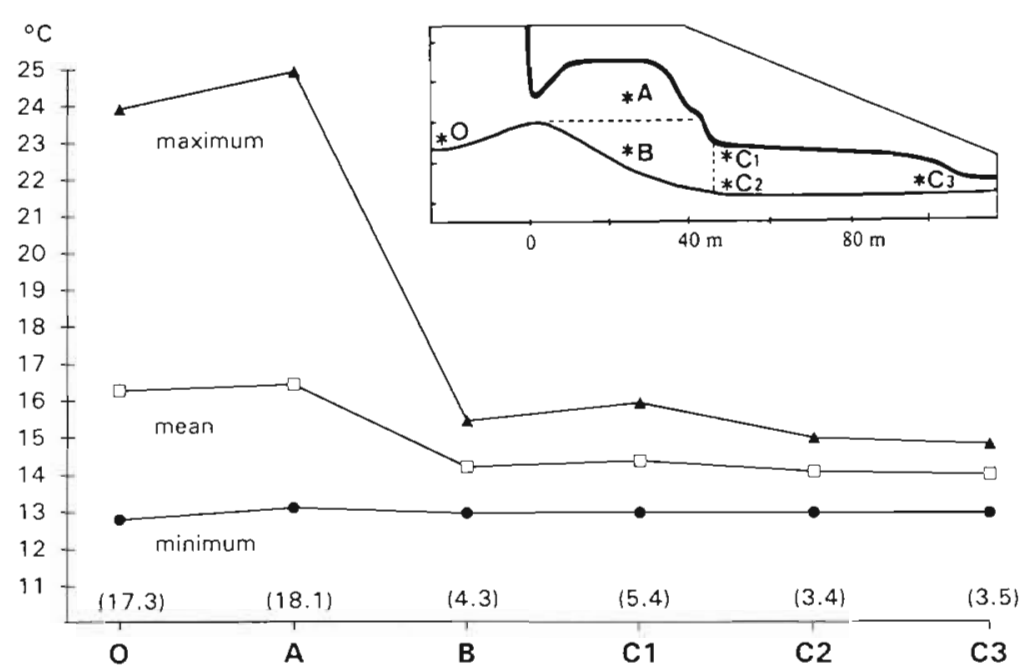

Fig. 4. Maximum, average and minimum temperatures recorded at 1 opensea station $(O)$ and 5 within-cave stations $(A, B, C 1-3)$ during a yearly cycle (7 July 1995 to 3 July 1996: 3597 measurements). Numbers in brackets above $x$-axis: coefficients of variation of corresponding mean temperatures

\section{Regional pool of encrusting bryozoans from the slope}

Erect growth forms do not occur in dark blind caves (except for scarce, small Crisia sp.). Therefore, only encrusting forms were considered as potential colonizers of 3PP Cave among species recorded in the Gulf of Lions in homothermal conditions (i.e. below 70 to $90 \mathrm{~m}$ depth). These encrusting species belong to 3 of the 4 depth-range categories previously defined (Fig. 3). Among the 77 species that constitute the regional pool of deep-water encrusting species, 19 species can be considered as stenobathic and are the most reliable potential indicators of shoreward transfers from deep-water habitats (Table 2). The remaining 58 species are eurybathic (18 ECB species, and 40 ESG species). The stenobathic stock is characterized by the lack of cyclostomes and by a relatively high proportion $(31.6 \%)$ of anascan cheilostomes.

outside temperature declined below the temperature reached by the inner cave water at this period of the year, i.e. $14.5^{\circ} \mathrm{C}$. The same phenomenon also occurred episodically during the warm season as short, sudden events when the northwesterly Mistral wind blew and induced strong upwellings from subthermocline layers. Typical illustrations of this pattern are given by 2 events that occurred on 27-28 August 1995 and 21-22 June 1996: in both cases, Mistral wind started blowing on the first day, reaching, on the second day, respectively, peak values of 31 and $28 \mathrm{~m} \mathrm{~s}^{-1}$ and mean values of $13.6 \pm 4.2$ and $13.3 \pm 3.1 \mathrm{~m} \mathrm{~s}^{-1}$ (data from the Marignane meteorologic station). The temperature drop resulting from shoreward transfers of uplifted cool water was then very rapid and reached $8^{\circ} \mathrm{C}$ in $24 \mathrm{~h}$ during the 2 events at both the open-sea station $(-18 \mathrm{~m})$ and the Zone A cave station $(-13 \mathrm{~m})$. Consequently, Zone A was rapidly emptied and refilled with denser-colder water from outside. The frequency of these Zone A emptying events reached 1 per month during the warm season (April to November) in both 1995 and 1996. The effectiveness of horizontal inward transfers of outside water in Zones B and C was attested to by the spread of temperature drops along the longitudinal gradient after a sudden destratification of the A and B water bodies. The velocity of this transfer, evaluated from time intervals between successive occurrences of the same temperature drop event at increasing distances from the entrance, ranged from 2.5 to $6.3 \mathrm{~m} \mathrm{~h}^{-1}$ during summer and autumn downwelling events.

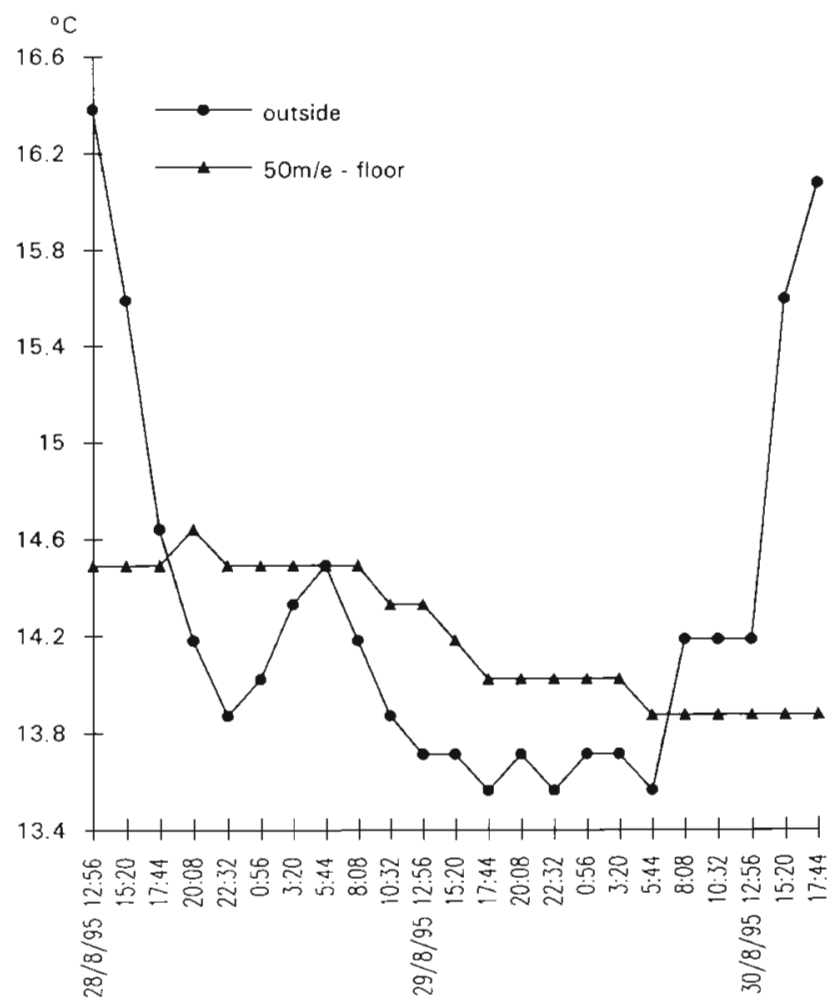

Fig. 5. Temperature records (28 to 30 August 1995) illustrating a sudden temperature drop in the open sea corresponding to a wind-induced upwelling event, and a cave downwelling resulting from water density reversal observed near the floor at $50 \mathrm{~m}$ from the cave entrance. Dates given as $\mathrm{d} / \mathrm{mo} / \mathrm{yr}$ 


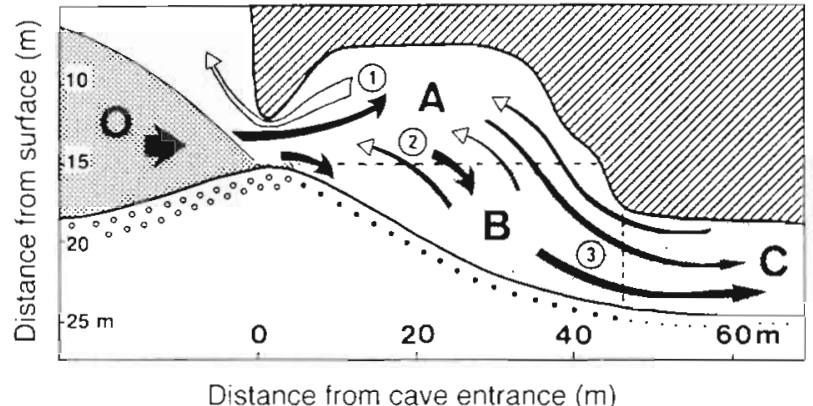

Fig. 6. Diagrammatic representation of water exchanges occurring in 3PP Cave when water uplifted from intermediate depth (O) spreads towards the cave's mouth and when its temperature $(\theta)$ is cooler than that of the withun-cave water bodies $(\theta O<\theta B<\theta A)$. (1) Emptying-refilling of Zone $A_{\text {, }}$ (2) destratification of $A / B$ water bodies, (3) horizontal water transfer throughout zones $\mathrm{B}$ and $\mathrm{C}$

By contrast, these 2 groups are equally represented (respectively 10 and 11 species) in the eurybathic stock.

\section{Actual bryozoan pool from 3PP Cave}

The whole bryozoan assemblage censused in 3PP Cave comprised 53 species, i.e. 20 species in eurythermal Zone A and 47 species in homothermal Zones B and $\mathrm{C}$. Six species were present only in Zone $\mathrm{A}$ and 33 species only in Zones B and C. All species recorded beyond the cave bend (Zone $C$ ) also occurred in Zone B, except for an infrequent Crisia sp.
The total number of species recorded at each station diminished inwardly in both eurythermal $(12 \mathrm{~m} / \mathrm{e} \rightarrow$ $25 \mathrm{~m} / \mathrm{e}: 28 \%$ ) and homothermal $(25 \mathrm{~m} / \mathrm{e} \rightarrow 100 \mathrm{~m} / \mathrm{e}:$ $75 \%$ ) zones (Fig. 7). In the homothermal layer, the inward decline of species richness was strongly related to the distance from the cave entrance by a linear regression $\left(\mathrm{r}^{2}=0.990, y=50.69-0.42 x\right)$. This distancerelated decline in species richness through the homothermal zones did not equally affect the different bryozoan groups: there was a steady inward increase in the proportion of cyclostome species in the bryozoan stock present on the walls. In other words, the number of cyclostome species remained constant from $25 \mathrm{~m} / \mathrm{e}$ to $80 \mathrm{~m} / \mathrm{e}$ (9 species) and diminished slightly afterwards while the number of cheilostome species regularly diminished inwardly (Fig. 7).

In both eurythermal and homothermal parts of 3PP Cave, the bryozoan pool comprised stenobathic shallow-water species (SSW, Fig. 8) that were absent from deep-water collections. Only 1 stenobathic deep-water species, Puellina setiformis Harmelin \& Aristegui, 1988 , was found in the cave; it occurred on walls of Zones $\mathrm{B}$ and $\mathrm{C}$ but not those of Zone $\mathrm{A}$. This cribrimorph was represented by infrequent colonies scattered below $-18 \mathrm{~m}$ depth from $25 \mathrm{~m} / \mathrm{e}$ to $80 \mathrm{~m} / \mathrm{e}$. It was known from 3 Mediterranean localities $(100$ to $300 \mathrm{~m}$ depth) and had never been recorded previously from caves or other shallow-water habitats (Harmelin \& Aristegui 1988). The SSW species were proportionally more numerous in eurythermal Zone A than in the cold part of the cave (Fig. 8). Comparisons of the latter with the dark parts of a nearby large karstic cave, Trémies

Table 2. Stenobathic deep-water encrusting bryozoans recorded in the Gulf of Lions. The only species found in $3 \mathrm{PP}$ Cave was Puellina setiformis

\begin{tabular}{lcc} 
Stenobathic deep-water species & Minimum recorded depth (Gulf of Lions) & Maximum depth (Mediterranean) \\
\hline Aplousina filum Jullien, 1903 & $65 \mathrm{~m}$ & $110 \mathrm{~m}$ \\
Aplousina capriensis (Waters, 1898) & $65 \mathrm{~m}$ & $100 \mathrm{~m}$ \\
Amphiblestrum lyrulatum (Calvet, 1907) & $80 \mathrm{~m}$ & $280 \mathrm{~m}$ \\
Amphiblestrum flemingii (Busk, 1854) & $230 \mathrm{~m}$ & $350 \mathrm{~m}$ \\
Copidozoum exiguum (Barroso, 1920) & $175 \mathrm{~m}$ & $2700 \mathrm{~m}$ \\
Hincksina sceletos (Busk, 1858) & $150 \mathrm{~m}$ & $300 \mathrm{~m}$ \\
Puellina arrecta Bishop \& Househam, 1987 & $120 \mathrm{~m}$ & $450 \mathrm{~m}$ \\
Puellina pseudoradiata Harmelin \& Aristegul, 1988 & $150 \mathrm{~m}$ & $524 \mathrm{~m}$ \\
Puellina setiformis Harmelin \& Aristegui, 1988 & $150 \mathrm{~m}$ & $300 \mathrm{~m}$ \\
Escharella octodentata (Hincks 1880) & $100 \mathrm{~m}$ & $200 \mathrm{~m}$ \\
Escharella ventricosa (Hassall, 1842) & $105 \mathrm{~m}$ & $250 \mathrm{~m}$ \\
Escharina johnstoni (Quelch, 1884) & $100 \mathrm{~m}$ & $100 \mathrm{~m}$ \\
Escharoldes megarostris (Canu \& Bassler, 1928) & $200 \mathrm{~m}$ & $300 \mathrm{~m}$ \\
Hemicyclopora discrepans (Jullien, 1903) & $115 \mathrm{~m}$ & $205 \mathrm{~m}$ \\
Phyllactellipora eximia (Hincks, 1860) & $105 \mathrm{~m}$ & $300 \mathrm{~m}$ \\
Schizoporella mutabilis Calvet, 1927 & $115 \mathrm{~m}$ & $300 \mathrm{~m}$ \\
Schizoporella neptuni (Jullien, 1882) & $120 \mathrm{~m}$ & $900 \mathrm{~m}$ \\
Smittina crystallina (Norman, 1967) & $200 \mathrm{~m}$ & $523 \mathrm{~m}$ \\
Trypostega claviculata (Hincks, 1884) & $100 \mathrm{~m}$ & $200 \mathrm{~m}$
\end{tabular}




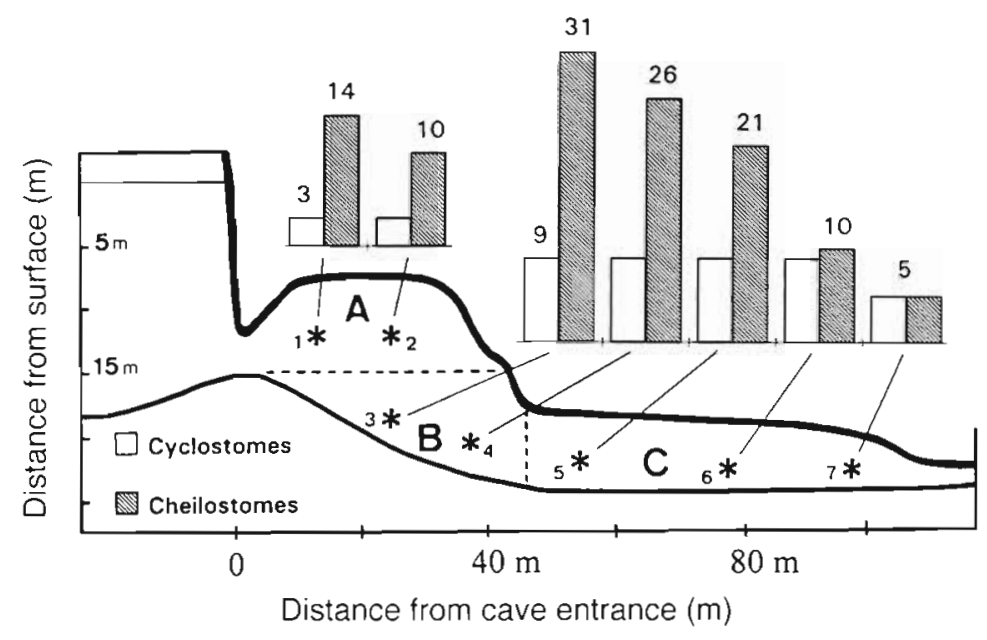

Fig. 7. Change in bryozoan (cyclostomes vs cheilostomes) species richness according to the distance from 3PP Cave's entrance. The numerals (= histobar scale) correspond to the total number of species recorded at each station (cf. Table 1)

Cave, indicate that their bryozoan pools are similar in size (47 vs 46 species) and that their structures in depth-range categories (Fig. 8) are not significantly different $\left(\chi^{2}=0.30, \mathrm{df}=2, P\right.$. setosa counted with ECB species). However, their species compositions are only moderately similar (Jaccard coefficient $=0.47$ ). Some of the most frequent species in Trémies Cave and other dark karstic caves of the study area, such as Coronellina fagei (SSW), Hincksina flustroides (ESG), Porella minuta (ECB), and Eurystrotos compacta (SSW), were completely absent from 3PP Cave (except for $C$. fagei, present in Zone A). These species and those present in 3PP Cave but not recorded in Trémies Cave show no particular depth-related trend.

\section{Bryozoan zooid size in relation with habitat}

In 5 (Escharina dutertrei, Fenestrulina malusii, Puellina cassidainsis, $P$. innominata, $P$. pedunculata) of the 6 eurybathic species considered for size analysis (Fig. 9), zooid length was clearly smaller in the eurythermal cave situations (karstic caves and 3PP Zone A) than in both 'cold' homothermal situations (deep-water biotopes and 3PP Zones B and C). Mean zooid lengths of colonies from the 3PP homothermal part were apparently not different ( $P$. cassidainsis, $P$. pedunculata), were smaller ( $E$. dutertrei, $F$. malusii), or were larger ( $P$. innominata) than that of deep-water biotopes. In the sixth species ( $P$ uellina radiata), the discrimination between eurythermal and 'cold' homothermal conditions was not observed: average zooid length was seemingly not different in deep-water biotopes and eurythermal shallow caves, but was clearly larger in the 3PP homothermal zones.

\section{Patterns of wall occupation}

The spatial distribution of sponges and bryozoans displayed quite different patterns. In both the eurythermal and stenothermal zones, the bryozoan cover decreased sharply with distance from the entrance (Fig. 10). This decline became very marked beyond the cave bend, resulting from both a decrease in colony frequency and smaller colony sizes. Ovicells were also rarer in colonies from Zone $\mathrm{C}$, although they were recorded in most species. The variance of the bryozoan cover was positively related to distance from the entrance (coefficient of variation: $76 \%$ at $25 \mathrm{~m} / \mathrm{e}, 125 \%$ at $40 \mathrm{~m} / \mathrm{e}, 178 \%$ at $60 \mathrm{~m} / \mathrm{e}$ ), attesting to an inward rise in colony scattering. Sponges were dominant throughout the cave (Fig. 10). In the eurythermal area, they occupied roughly half of the wall surface, with no significant inward change. In the homothermal area, the sponge cover was slightly lower but was very even along the whole spatial gradient, with individuals presenting a wide size range.

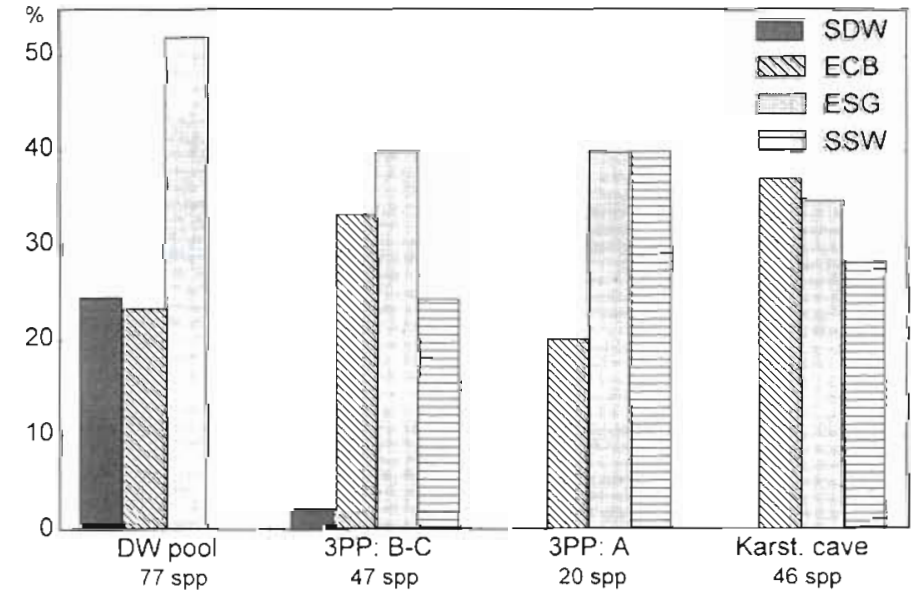

Fig. 8. Depth-range distribution of species recorded in 4 bryozoan assemblages from deep-water habitats (DW pool), homothermal Zones $\mathrm{B}$ and $\mathrm{C}$ (3PP: $\mathrm{B}-\mathrm{C}$ ) and eurythermal Zone A (3PP: A) of 3PP Cave, and a karstic cave (Trémies Cave). SDW: stenobathic deepwater species; ECB: eurybathic cryptobathyal species; ESG: eurybathic sciaphilous generalists; SSW: stenobathic shallow-water species 

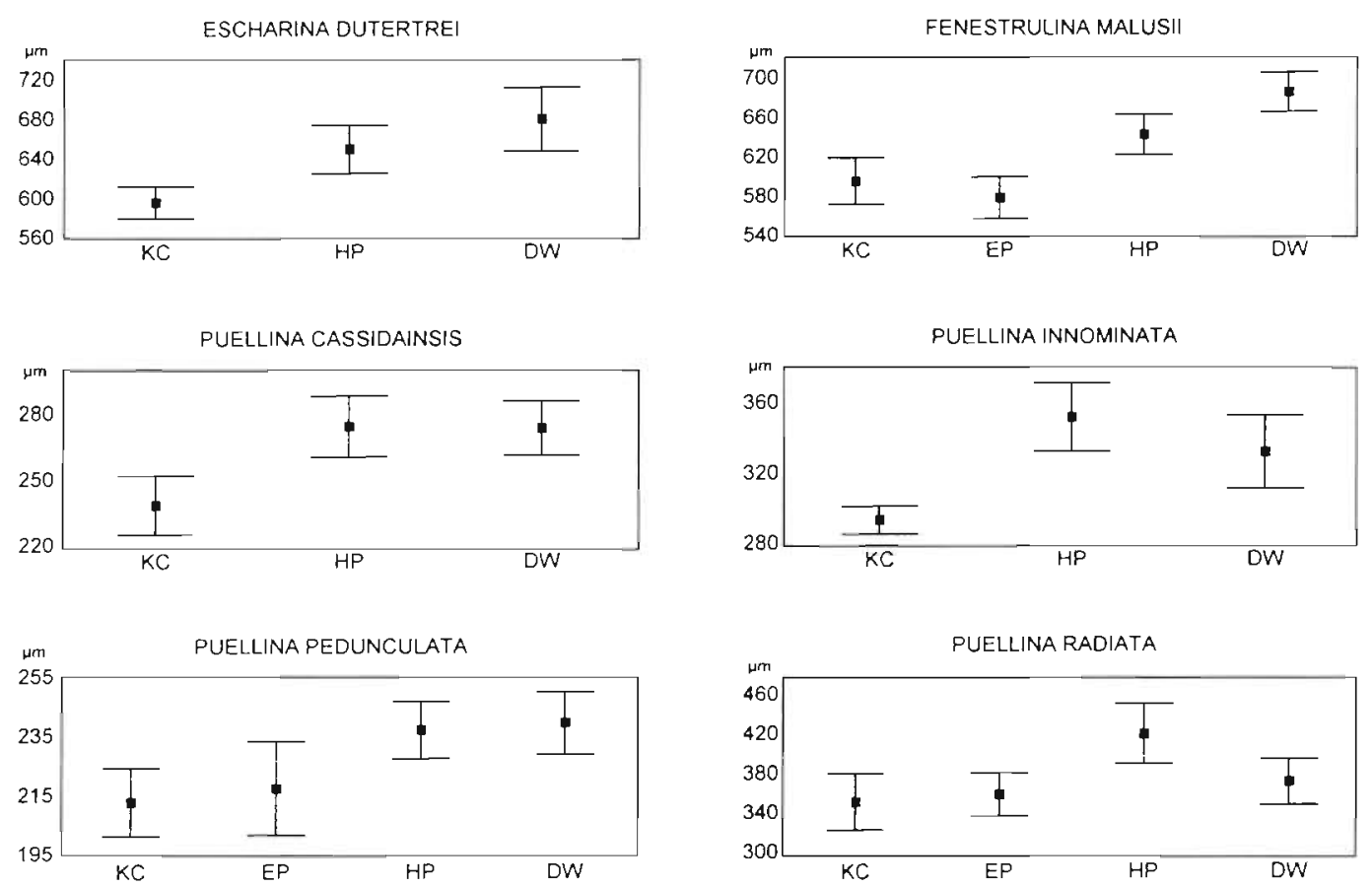

Fiy. 9. Mifean zooid iengin (frontai sheath ior Fueilina spp.) in b eurybathic species from a karstic cave (KC), eurythermal Zone A (EP) and homothermal Zones $\mathrm{B}$ and $\mathrm{C}(\mathrm{HP})$ of $3 \mathrm{PP}$ Cave, and deep-water habitats (DW). Average values $\pm \mathrm{SD}$ calculated from 10 within-colony means per habitat type

\section{Colonization rate}

After a 14 mo immersion, the artificial substrates were very differently colonized in the eurythermal and homothermal zones of 3PP Cave. The colonization rate was surprisingly low in the homothermal sec-

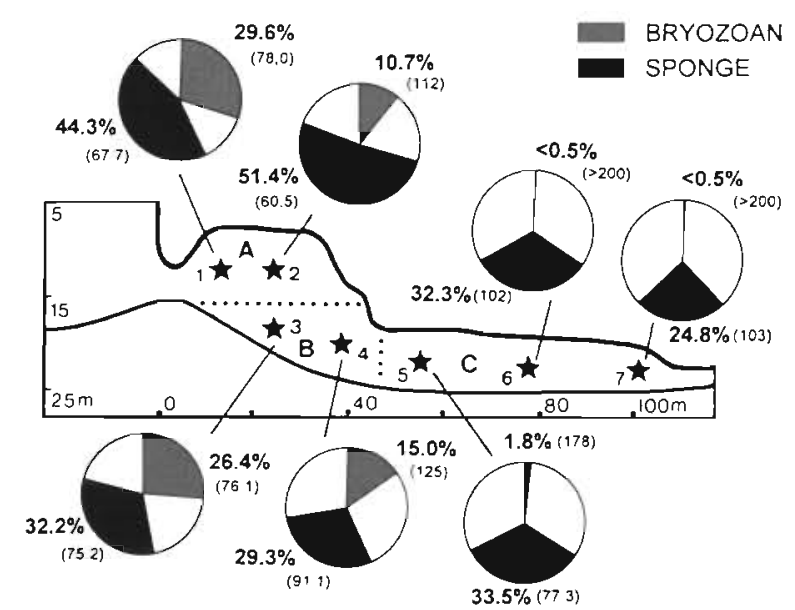

Fig. 10. Changes in bryozoan and sponge abundance (mean percent cover, coefficient of variation in brackets) along Zones A (eurythermal), B and C (homothermal) of 3PP Cave at increasing distances from the entrance (A: 12 and $25 \mathrm{~m} / \mathrm{e}_{i}$ B: 25 and $40 \mathrm{~m} / \mathrm{e} ; \mathrm{C}: 60,80$ and $100 \mathrm{~m} / \mathrm{e})$ tion. At $50 \mathrm{~m} / \mathrm{e}(-22 \mathrm{~m}$, Zone $\mathrm{C})$ the plates bore no bryozoan colonies or other macroscopic settlers; at $25 \mathrm{~m} / \mathrm{e}(-20 \mathrm{~m}$, Zone B) only 7 bryozoan colonies belonging to 2 common species (Aetea sica, Fenestrulina malusii) were present on 2 panels ( 32 plate faces $=12000 \mathrm{~cm}^{2}$ ) deployed near the left wall and above the median cave axis (Fig. 11). In eurythermal Zone A $(-13 \mathrm{~m})$, the colonization rate was considerably higher on both panels and the highest species richness and colony abundance occurred on the panel nearest the cave entrance. Among the 32 species recorded on those A-panels, 18 species have not been recorded on the cave walls $(55.6 \%$ of the settlers' stock at $12 \mathrm{~m} / \mathrm{e}$, $55 \%$ at $25 \mathrm{~m} / \mathrm{e}$ ). These 'new' species were dominant in terms of colony number at $12 \mathrm{~m} / \mathrm{e}(77 \%$ of the overall abundance) and less abundant at $25 \mathrm{~m} / \mathrm{e}$ (32\%). In contrast to the wall assemblages, the A-panels bore erect species (e.g. Scrupocellaria scrupea, Caberea boryi, Savignyella lafontii) that were among the most abundant settlers, especially at $1.2 \mathrm{~m} / \mathrm{e}$. The structure in depth-range categories of the bryozoan assemblage on A-panels was similar to that occurring on adjacent walls $\left(\chi^{2}=0.48, \mathrm{df}=2\right)$ but was significantly different from that of walls of the homothermal zones $\left(\chi^{2}=\right.$ $6.08, \mathrm{df}=2, \mathrm{p}<0.05)$, with a lower proportion of eurybathic cryptobathyal species $(9.4 \%$ vs $29.8 \%)$. No stenothermal deep-water species was recorded among the settlers. 


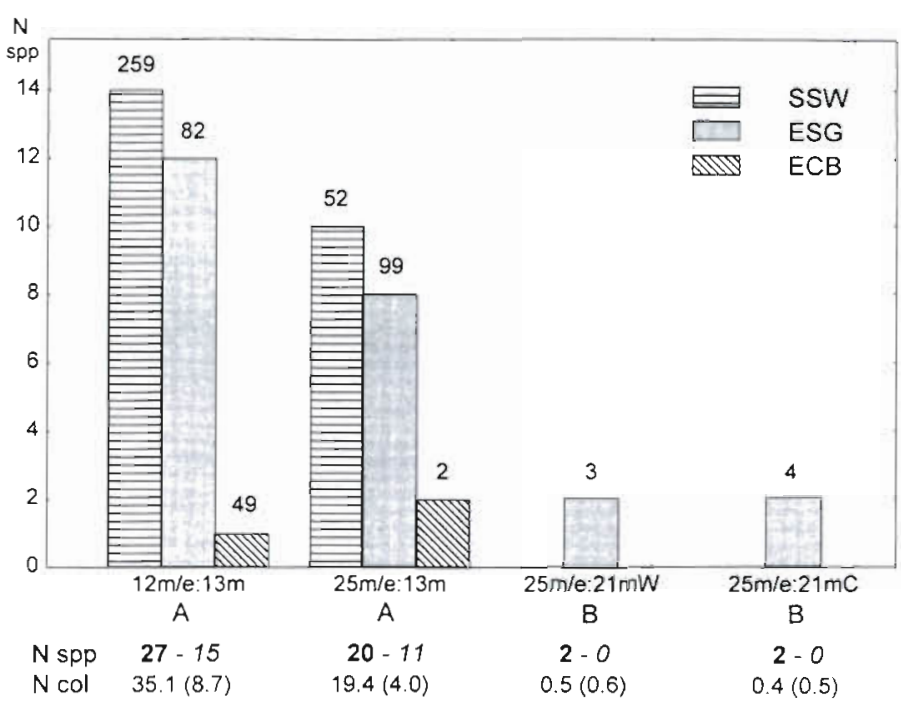

Fig, 11 Colonization rates of bryozoans on panels (each panel $=8$ perspex plates $\times 2$ faces $=3000 \mathrm{~cm}^{2}$ ) immersed during $14 \mathrm{mo}$ in $3 \mathrm{PP}$ Cave at 2 stations in Zone A ( $-13 \mathrm{~m}: 12 \mathrm{~m} / \mathrm{e}, 25 \mathrm{~m} / \mathrm{e})$ and 2 stations in Zone B (-21 m: $25 \mathrm{~m} / \mathrm{e}$ near wall, and $25 \mathrm{~m} / \mathrm{e}$ center). Number of species (histobars) and colonies (numerals above bars) in 3 depth-related categories (SSW: stenobathic shallow-water species; ESG: eurybathic sciaphilous generalists; ECB: eurybathic cryptobathyal species). N spp: whole species number (in bold) and number of 'new species' (i.e. those not recorded on cave walls, in italics); $N$ col: average number (SD) of colonies per plate $\left(2\right.$ faces $=375 \mathrm{~cm}^{2}$ )

\section{DISCUSSION}

The actual bryozoan pool of 3PP Cave comprises only 1 stenobathic species from subthermocline habitats, namely Puellina setiformis, while 6 SDW sponge species are recorded in the cave. This difference appears less significant when considering the ratio cave pool/regional pool in bryozoans $(1: 19 \approx 0.05)$ and sponges $(6: 61 \approx 0.1$, SDW regional pool calculated from Vacelet 1969, considering all growth forms). However, the within-cave occurrence of $P$. setiformis has only a moderate significance: its SDW character is not yet fully ascertained (Puellina comprises many ECB species, Harmelin 1988) and this bryozoan is only known from a few records from the upper part of the subthermocline zone $(-100$ to $-300 \mathrm{~m})$. These features contrast with that of the deep-sea organisms found in 3PP Cave: the cladorhizid Asbestopluma hypogea, abundant in outer Zone $B$, is a representative of the deepest known genus $(-8840 \mathrm{~m}$ ) of sponges (Vacelet \& Boury-Esnault 1995); hexactinellids, to which Oopsacas minuta belongs, are one of the most typical deepsea taxa; the demosponge Hamacantha implicans is characteristically associated with the deep-sea coral community (Vacelet 1969, in press); the tartigrad Trogloarctus trionyches belongs to the deep-sea family Coronarctidae (Villora-Moreno 1996); and the spoke- like traces left by the undescribed echiuran on the cave floor are very similar to those observed in the abyssal zone (Vacelet et al. 1994). Successful colonization of 3PP Cave by stenobathic deep-water species is seemingly not related to their frequency in the source communities. By contrast, common SDW species, such as the sponges Reniera magna, Tylodesma inornata, and Poecillastra compressa (Vacelet 1969) or the bryozoans Smittina crystallina, Puellina arrecta, and Escharella ventricosa, do not colonize $3 \mathrm{PP}$ Cave. This lack of success may have 3 alternative causes: (1) propagules of these species are not uplifted from deep-water habitats, (2) they are uplifted but are unable to reach the target cave, (3) they are present in the downcave flow but local conditions are adverse to recruitment or population development.

\section{Suitability of physical conditions}

Cross-shelf deep-water export

Though downcanyon circulation predominates in the Canyon of Cassidaigne (Bourcier 1978, Macquart-Moulin \& Patriti 1993), sudden uplifting of bottom water with material advected throughout the water column is observed under particular wind conditions (Bourcier 1978). Modelling indicates that, in the same area, the forcing conditions involving the general geostrophic circulation (Northern Current $=$ Liguro-Provençal-Catalan current) and a strong northwesterly wind (Mistral) of $14 \mathrm{~m} \mathrm{~s}^{-1}$ generate upwelling velocities up to $10 \mathrm{~m} \mathrm{~h}^{-1}$ (Pinazzo et al. 1996). As stressed by Sur et al. (1996), mesoscale hydrodynamic features and boundary currents are of prime importance in determining cross-shelf exchanges with the deep sea in areas with a steep bottom profile. The very strong upwelling events that episodically occur in the study region, and which are associated with meandering motions of the geostrophic circulation (Millot 1991, Conan \& Millot 1995), might allow larvae produced by deep-water benthic organisms to be advected shoreward with their surrounding water parcels, as suggested by Mullineaux (1994) for mesoscale hydrodynamic processes related to seamounts. Winds driving these upwellings are not predictable and the atmospheric forcing that causes them may occur at any time of the year. On the contrary, the internal tidal bores, another type of mesoscale process which also induces upwellings, temperature drops in surface layers, and onshore transport of larvae, are predictable within the lunar cycle (Pineda 1991, 1994). 
Target cave hydrology

Temperature recordings confirm the nearly homothermal regime of the inner parts of the cave, below the entrance floor level. This marked temperature constancy around winter values, very unusual in the coastal zone, is similar to that occurring below $80 \mathrm{~m}$ depth (Conan 1996). As the sole supply of cool water comes from the open sea, this thermal regime suggests a long residence time of the water body filling the cave, particularly during the warm season (Vacelet et al. 1994). However, destratification by reversal of the temperature ratio in the outer cave chamber (Zones $A / B)$ appears to occur more frequently than formerly postulated. The within-cave circulation induced by Zone A emptying and being refilled by colder water involves the sudden import of large volumes of water uplifted from subthermocline depths and presumably carrying advected material

Thus, the episodic cross-shelf and downcave inputs of water parcels upwelled from the nearby canyon are the most plausible key factor determining the unusual presence of bathyal organisms in 3PP Cave.

\section{Biological data}

\section{Dispersal capacities}

Like most bryozans, all species belonging to the regional deep-water pool brood lecithotrophic larvae, with a seemingly very short ( 1 to $5 \mathrm{~h}$ ) free life after release (Ryland 1976, 1981, Jackson 1986, Orellana et al. 1996). Flexibility in development leading to extended competence and delayed settlement of lecithotrophic larvae is observed in various taxa (Pechenik 1990). Some observations indicate that bryozoan larvae are able to delay settlement to some extent (time lags ranging from 8 to $48 \mathrm{~h}$ ) when suitable microhabitats are not available (Cook 1968, Cancino et al. 1994) and that capability to delay settlement decreases when larvae have to swim actively (Orellana \& Cancino 1991). The dispersal capacities of bryozoan larvae are thus limited to distances ranging from centimeters to a few kilometers (McKinney \& Jackson 1989). However, it is likely that particular physical conditions such as those of the study region allow bryozoan larvae to be upwelled from subthermocline bottoms and advected onshore. On the other hand, although colony fragmentation and colony rafting by means of drifting substrates are considered to be major mechanisms of long-distance dispersal (Jackson 1986, McKinney \& Jackson 1989), upward transportation of bryozoan colonies encrusting deep-water rocks or shells is very unlikely.
Most sponges have lecithotrophic larvae with a short planktonic life, but various patterns of sexual and asexual production of propagules favouring mesoscale dispersal also occur in this group: pelagic armoured larvae and spiculate plasmodes, external buds, fragmented body portions (Brien et al. 1973). Asexual fragmentation is a significant mode of dispersal for erect sponges (Wulff 1991) that may be more efficient than propagules issued from sexual reproduction. The bathyal aliens Oopsacas minuta and Asbestopluma hypogea are delicate, erect forms that can be easily fragmented and are likely to have a good drifting capacity. In situ observations indicate that $O$. minuta is not firmly attached to the cave walls: individuals can be detached and dragged several meters by manmade turbulences. On the other hand, the fact that the larvae of $O$. minuta are rich in lipids and yolk and have multiflagellated cells (Boury-Esnault \& Vacelet 1994, Vacelet 1996) may be indicative of their dispersal efficiency (Kelly-Borges 1995). Moreover, the successful development of many individuals of $O$. minuta on PVC stakes and lines deposited above the muddy floor 4 yr ago from 80 to $110 \mathrm{~m} / \mathrm{e}$ (author's unpubl. data) attests to the capability of this species to colonize discrete substrates thanks to larval dispersal. Similar though less spectacular indications are given by the cave population of Asbestopluma hypogea.

\section{Indications from the target cave community}

The great similarity in bryozoan richness found in homothermal 3PP Cave and eurythermic Trémies Cave despite their different thermal regimes is worth noting. Considering that both caves have many traits in common (large size, total darkness, same entrance depth, localization in the same bay) and received roughly the same sampling effort, it could be tempting to relate this result to the predictions of the theory of island biogeography (MacArthur \& Wilson 1967): convergent richness patterns should simply result from the balance between immigration and extinction in these similarly sized ecological islands, the differences in species composition found between these cave assemblages being attributed to chance recruitment from common regional pools of eurythermic sciaphilous species (ESG, ECB). However, the area effect, rejected by Culver (1970) for terrestrial caves, has yet to be tested in marine cavities.

The almost total exclusion of bryozoans from Zone C while sponges seem not to be affected by distance from the entrance is somewhat intriguing. There is no easily perceptible physical modification introduced by the change in the cave's orientation. Salinity, oxygen and chlorophyll pigment contents in the homothermal layer 
show no clear changes from $25 \mathrm{~m} / \mathrm{e}$ to $100 \mathrm{~m} / \mathrm{e}$ at $20 \mathrm{~m}$ depth (J. C. Romano pers, comm.). However, these observations concern the median part of the cave water body and not the layer adjacent to walls. The reduced size of colonies and the rarity of ovicells among bryozoans from Zone $\mathrm{C}$ (the occasional presence of ovicells does not imply that competent larvae are released) may be indicative of a change in the abiotic environment beyond the cave turn. As this cave is a blind tunnel, water stagnation is likely to increase with distance from entrance and to be enhanced by the cave turn, especially in the layer close to the walls. The diminution of food inputs below a critical level within the wall boundary layer may lead to reproduction failure and allocation of energy only to vegetative survival of colonies. According to this hypothesis, the persistence of a bryozoan stock in Zone $\mathrm{C}$ would depend on scarce imports of recruits, mainly from Zone B colonies, and also on exceptional food inputs that could trigger local reproduction. The sporadic within-cave downwellings may play a crucial role in these processes, leading the Zone $\mathrm{C}$ bryozoan populations to be controlled by unpredictable pulses of imported particles, a pattern evoking some deep-sea conditions (Gage \& Tyler 1991, Tyler \& Young 1992). These features of Zone C, particularly extended empty space and population levels limited by abiotic factors, would indicate a non-interactive system where richness is not influenced by local interactions (Cornell \& Lawton 1992). However, in this food-limited biotope, even slight biotic interactions affecting the food resources shared by suspension-feeders may have a crucial role in worsening the effects of water stagnation. An increasing body of evidence suggests that sponges can be highly interactive with coexisting invertebrates (Goodbody 1961, Jackson \& Buss 1975, Dyrinda 1985, Pawlik 1992, but see Bingham \& Young 1991). The dense colonization of the whole of Zone C from $50 \mathrm{~m} / \mathrm{e}$ to $110 \mathrm{~m} / \mathrm{e}$ by the deep-sea sponge Oopsacas minuta (100 ind. $\mathrm{m}^{-2}$, Vacelet et al. 1994) might be the worsening biotic parameter: this hexactinellid is a most efficient filter feeder, characterized by a highly developed aquiferous system and a great capacity for particle retention (Perez 1996).

\section{Indications from bryozoan morphometry}

The difference in bryozoan zooid size found among eurythermal shallow-water cryptic situations and homothermal 'cold' environments in 5 out of 6 species analysed provides clear evidence of a relationship between zooid size and temperature. A similar trend has been evidenced by laboratory experiments (Menon 1972, Hunter \& Hughes 1994), by biometrics of specimens collected at different depths in the same region (Gautier 1962, Harmelin 1988), and by specimens coming from regions (Ryland 1963, Silén \& Harmelin 1976) or geological times (Okamura \& Bishop 1988) with different climates. The mechanisms by which body size of poikilotherms decreases at higher temperatures are still speculative (review by Hunter \& Hughes 1994), and the relationship with energy intake suggested by field observations has not been confirmed by culture experiments on a bryozoan species (Hunter \& Hughes 1994). The present results might be interpreted in terms of palaeotemperatures. Interestingly, 2 of the species treated here, Escharina dutertrei and Fenestrulina malusii, were among those presenting the clearest evidence of correlation between the increase in zooid length and the drop in temperature around the British Isles since Coralline Crag time (Okamura \& Bishop 1988). In contrast to observations on 5 other species, the constant lower temperature occurring in deep-water habitats has apparently no effect on zooid size of Puellina radiata, although a similar temperature regime appears to cause a marked size increase in colonies from 3PP Zones B and C (Fig. 9). This pattern suggests that the deep-water population may be genetically differentiated from the shallower one and, furthermore, that the 3PP Cave population does not have a deep-water origin.

\section{Indications from settlement experiments}

The settlement experiments emphasize the difference between the eurythermal and homothermal sections of the cave. The large number of 'new' species, i.e. those unknown from 3PP walls but that colonized the Zone A plates, attests that this part of the cave is supplied by allochthonous larvae. The identity of these new species indicates that the source populations are located in coastal and not in deep-water biotopes. The success of erect species on those panels is surprising as this growth-form is unknown from cave walls. This exclusion, observed in all sessile taxa, has been attributed to poorer filtering efficiency in still water and higher energy cost for constructing a colony with the same number of zooids (Harmelin et al. 1985, Harmelin 1986). The occurrence of erect bryozoans on zone A plates may be related to modifications of the small-scale flow regime generated by these 3-d structures, which have no equivalent among cave natural substrates. As stressed by Pawlik (1992), the role of hydrodynamic processes in settlement has to be more thoroughly investigated in natural situations. The very low settlement rate observed on panels deposited in the homothermal layer confirms the weak dynamics of dark cave communities 
already observed in a karstic cave (Trémies Cave Harmelin 1985): after $9 \mathrm{yr}$, the bryozoan cover on limestone plates was only $3.1 \%$ of the surface area ( $28.3 \%$ on adjacent walls). The absence of turbulences within caves that could break the sequestration of larvae released within the boundary layer may be responsible for the poor capability of these larvae to settle on discontinuous substrates. However, a higher settlement rate was expected on panels from. Zone $\mathrm{B}$, considering the water exchanges occurring in this zone close to the cave entrance and adjacent to Zone A where panels are densely colonized. The rapid sedimentation of advected larvae (Garrabou \& Flos 1995) or, conversely, the poor ability of these larvae to cross the $A / B$ thermal front may explain this discrepancy.

\section{Conclusions}

The occurrence of successful deep-sea species in the homothermal 3PP Cave brings evidence that the dark cave community is not a closed system from which components of other aphotic communities are excluded.

The episodic cross-shelf and downcave inputs of water parcels upwelled from the nearby canyon are the most plausible key factor determining the unusual presence of these bathyal organisms in 3PP Cave by establishing a within-cave cold homothermy and advecting propagules from the slope. In the absence of genetic data, there is no indication whether each population of the bathyal organisms occurring in 3PP Cave was established from a single founder event, i.e. arrival of a single larval cohort, or were recruited episodically from allochthonous larvae. The very small size of the target, i.e. the cave entrance $\left(<4 \mathrm{~m}^{2}\right)$, considerably reduces the probability that events of propagule supply from the deep sea may occur frequently.

The poor success in this cave of stenobathicstenothermic bryozoans from deep-water habitats, as well as the marked decrease in richness and abundance of the whole bryozoan assemblage beyond a critical distance from the cave entrance may result from the cumulated effects of abiotic and biotic factors. Weak capabilities of bryozan larvae to disperse across offshore and within-cave thermoclines and afterwards in stagnant water combined with food-limiting species interactions likely involving sponges are hypothesized to be responsible for this taxon-specific distribution pattern. Thus, the present results suggest that the regional pool of deep-water bryozoans is not a probable source of settlers for nearshore aphotic habitats
Acknowlegements. I am grateful to N. Boury-Esnault, C Jalong, J. C. Romano, J Rubin, J Vacelet and H. Zibrowius for collaborative work interesting discussions and diving assistance. Four anonymous reviewers provided much appreclated comments on the manuscript. This research was supported by the French national programme 'Dynamique de la Biodiversité et Environnement' (PNDBE).

\section{LITERATURE CITED}

Bianchi CN, Morri C (1994) Studio bionomico comparativo di alcune grotte marine sommerse: definizione di una scala di confinamento. Mem Ist Ital Speleo Ser II, 6:107-123

Bingham BL, Young CM (1991) Influence of sponges on invertebrate recruitment: a field test of allelopathy. Mar Biol 109:19-26

Bonifay E, Courtin J (1980) Présence de littoraux immergés du Sicilien et du Tyrrhénien dans la région de Marseille (Bouches-du-Rhône). C R Acad Sci Paris (Sér D) 291: 143-145

Bourcier M (1978) Courantologie du canyon de Cassidaigne. Téthys 8:275-282

Boury-Esnault N, Vacelet J (1994) Preliminary studies on the organization and development of a hexactinellid sponge from a Mediterranean cave, Oopsacas minuta. In: Van Soest RWM, Van Kempen TMG, Braekman JC (eds) Sponges in time and space. Biology. chemistry: paleontology. Balkema, Rotterdain, p 407-415

Brien P, Lévi C, Sará M. Tuzet O, Vacelet J (1973) Spongiaires. Anatomie, physiologie, systématique, écologie. In: Grassé PP (ed) Traité de zoologie. Tome 3, fascicule 1 Masson et Cie, Paris

Cancino JM, Hughes RN, Orellana C (1994) A comparative study of larval release in bryozoans. In: Hayward PJ, Ryland JS, Taylor PD (eds) Biology and palaeobiology of bryozoans. Olsen and Olsen, Fredensborg, p 41-46

Cheetham AH, Hazel JE (1969) Binary (presence-absence) similarity coefficient. J Paleont 43:1130-1136

Cinell. F, Fresi E, Mazzella L, Pansini M, Pronzato R, Svoboda A (1977) Distribution of benthic phyto- and zoocoenoses along a light gradient in a superficial marine cave. In: Keegan BF, O'Ceidigh PO, Boaden PJS (eds) Biology of benthic organisms. Pergamon Press, Oxford, p 173-183

Conan $P$ (1996) Variabilité et bilan de la production primaire en zone côtière (Méditerranée nord-occidentale, entrée du Golfe du Lion) en relation avec les systèmes biologique, chimique et hydrodynamique (Courant Nord Méditerranéen). Thèse doctorat, Université d'Aix-Marseille II

Conan P, Millot C (1995) Variability of the Northern Current of Marseilles, western Mediterranean Sea, from February to June 1992. Oceanol Acta 18:193-205

Cook PL (1968) Observations on living Bryozod. Atti Soc Ital Sci Nat e Museo Civ Stor Nat Milano 108:155-160

Cornell HV, Lawton JH (1992) Species interactions, local and regional processes, and limits to the richness of ecological communities: a theoretical perspective. J Anim Ecol 61:1-12

Culver DC (1970) Analysis of simple cave communities. I. Caves as islands. Evolution 24:463-474

Dyrinda PEJ (1985) Chemical defences and the structure of subtidal epibenthic communities. In: Gibbs PE (ed) Proc 19th Eur Mar Biol Symp. Cambridge University Press. Cambridge, p 411-421

Fichez R (1990) Decrease in allochthonous organic inputs in dark submarine caves, connection with lowering in benthic community richness. Hydrobiologia 207:61-69 
Fichez R (1991a) Benthic oxygen uptake and carbon cycling under aphotic and resource-limiting conditions in a submarine cave. Mar Biol 110:137-143

Fichez R (1991b) Suspended particulate organic matter in a Mediterranean submarine cave. Mar Biol 108:167-174

Froget C (1974) Essai sur la géologie du précontinent de la Provence accidentale. Thèse doctorat Etat, Université d'Aix-Marseille Il

Gage JD, Tyler PA (1991) Deep-sea biology: a natural history of organisms at the deep-sea floor. Cambridge University Press, Cambridge

Garrabou J, Flos J (1995) A simple diffusion-sedimentation model to explain planktonic gradients within a NW Mediterranean submarine cave. Mar Ecol Prog Ser 123 $273-280$

Gautier JY (1962) Recherches écologiques sur les bryozoaires chilostomes en Méditerranée occidentale. Rel Trav Stn Mar Endoume 38 (24):1-434

Goodbody 1 (1961) Inhibition of the development of a marine sessile community. Nature (Lond) 190:282-283

Harmelin JG (1969) Bryozoaires des grottes sous-marines obscures de la région marseillaise. Faunistique et écologie. Téthys 1:793-806

Harmelin JG (1976) Le sous-ordre des Tubuliporina (Bryozoaires Cyclostomes) en Méditerranée. Ecologie et systématique. Mém lnst Océanogr (Monaco) 10:1-326

Harmelin JG (1985) Bryozoan dominated assemblages in Mediterranean cryptic environments. In: Nielsen C, Larwood GP (eds) Bryozoan: Ordovician to recent, Olsen \& Olsen, Fredensborg, p 135-143

Harmelin JG (1986) Patterns in the distribution of bryozoans in the Mediterranean marine caves. Stygologia 2:10-25

Harmelin JG (1988) Espèces affines microsympatriques chez Puellina (Bryozoa, Cheilostomata) et description d'espèces nouvelles. Zool Scr 17:25-38

Harmelin JG, Aristegui J (1988) New Cribrilinidae (Bryozoa, Cheilostomatal from the upper bathyal of the AtlantoMediterranean region. J Nat. Hist 22:507-535

Harmelin JG, Vacelet J, Vasseur P (1985) Les grottes sousmarines obscures: un milieu extrême et un remarquable biotope refuge. Téthys 11:214-229

Hunter E, Hughes RN (1994) The influence of temperature, food ration and genotype on zooid size in Celleporella hyalina (L.). In: Hayward PJ, Ryland JS, Taylor PD (eds) Biology and palaeobiology of bryozoans. Olsen \& Olsen. Fredensborg, p 83-86

Hurlbert SJ (1984) Pseudoreplication and the design of ecological field experiments. Ecol Monogr 54:187-211

Jackson JBC (1986) Modes of dispersal of clonal benthic invertebrates: consequences for species' distributions and genetic structure of local populations. Bull Mar Sci 39 $588-606$

Jackson JBC, Buss L (1975) Allelopathy and spatial competition among coral reef invertebrates. Proc Natl Acad Sci USA 72:5160-5163

Kelly-Borges M (1995) Sponges out of their depth. Nature 373:284

Laborel J, Vacelet J (1959) Les grottes sous-marines obscures en Méditerranée. C R Acad Sci Paris (Sér D) 248: $2619-2621$

MacArthur RH, Wilson EO (1967) The theory of island biogeography. Princeton University Press, Princeton, NJ

MacQuart-Moulin C, Patriti G (1993) Canyons sous-marins et advection vers le talus continental du plancton néritique Oceanol Acta 16:179-189

McKinney FK, Jackson JBC (1989) Bryozoan evolution. Unwin Hyman, Boston.
Menon NR (1972) Heat tolerance, growth and regeneration in three North Sea bryozoans exposed to different constant temperatures. Mar Biol 15:1-11

Millot C (1979) Wind induced upwellings in the Gulf of Lions Oceanol Acta 2:261-274

Millot C (1991) Mesoscale and seasonal variabilities of the circulation in the western Mediterranean. Dyn Atmos Oceans 15:179-214

Mullineaux LS (1994) lmplications of mesoscale flows for dispersal of deep-sea larvae. In: Young CM. Eckelbarger KJ (eds) Reproduction, larval biology, and recruitment of deep-sea benthos. Columbia University Press, New York p $201-222$

Okamura B, Bishop JD (1988) Zooid size in cheilostome bryozoans as an indicator of relative palaeotemperature. Palaeogeogr Palaeoclimatol Palaeoecol 66:145-152

Orellana MC, Cancino JM (1991) Effects of delaying larval settlement on metamorphosis and early colonial growth in Celleporella hyalina (Bryozoa: Cheilostomata). In: Bigey FP (ed) Bryozoaires actuels et fossiles: Bryozoa living and fossil. Bull Soc Sci Nat Ouest Fr Mém HS 1:309-316

Orellana MC, Cancino JM, Hughes RN (1996) Is settlement in lecithotrophic bryozoan larvae constrained by energy reserves? In: Gordon DP, Smith AM, Grant-Mackie JA (eds) Bryozoans in space and time. NIWA, Wellington, p 221-226

Pärtel M, Zobel M, Zobel K, van der Maarel E (1996) The species pool and its relation to species richness: evidence from Estonian plant communities. Oikos 75:111-117

Passelaigue F, Bourdillon A (1985) Thermographie de l'écosystème de quelques grottes sous-marines obscures Rapp Comm Int Mer Médit 29:155-156

Pawlik JR (1992) Chemical ecology of the settlement of benthic marne invertebrates. Oceanogr Mar Biol Annu Rev 30:273-335

Pechenik JA (1990) Delayed metamorphosis by larvae of benthic marine invertebrates: Does it occur? Is there a price to pay? Ophelia 32:63-94

Pérès JM. Picard J (1964) Nouveau manuel de bionomie benthique de la Mer Méditerranée. Rel Trav Stn Mar Endoume 47:5-137

Perez T (1996) La rétention de particules par une éponge hexactinellide, Oopsacas minuta (Leucopsacasidae): le rôle du reticulum. C R Acad Sci Paris 319:385-391

Pinazzo C, Marsaleix P. Millet B. Estournel C, Véhil R (1996) Spatial and temporal variability of phytoplankton biomass in upwelling areas of the northwestern Mediterranean: a coupled physical and biogeochemical modelling approach. J Mar Syst 7:161-191

Pineda J (1991) Predictable upwelling and the shoreward transport of planktonic larvae by internal tidal bores. Science 253:548-551

Pineda J (1994) Internal tidal bores in the nearshore: warmwater fronts, seaward gravity currents and the onshore transport of neustonic larvae. J Mar Res 52:427-458

Pirazzoli PA (1991) World atlas of Holocene sea-level changes. Elsevier, Amsterdam

Ricklefs RE (1987) Community diversity: relative roles of local and regional processes. Science 235:167-171

Riedl R (1966) Biologie der Meereshöhlen. Paul Parey, Hamburg

Roughgarden J, Gaines SD, Pacala SW (1987) Supply side ecology: the role of physical transport processes. In: Gee JHR, Giller PS (eds) Organization of communities - past and present. 27th Symp British Ecological Soc, Aberystwyth, 1986. Blackwell, Oxford, p 491-518

Ryland JS (1963) The species of Haplopoma (Polyzoa). Sarsia 10:9-18 
Ryland JS (1976) Behaviour, settlement and metamorphosis of bryozoan larvae: a review. Thalassia Jugosl 10 : 239-262

Ryland JS (1981) Colonies, growth and reproduction. In: Larwood GP, Nielsen C (eds) Recent and fossil Bryozoa. Olsen and Olsen, Fredensborg, p 221-226

Silén L, Harmelin JG (1976) Haplopoma sciaphilum sp. n., a cave living bryozoan from the Skagerrak and the Mediterranean. Zool Sc 5:61-66

Sur HI, Özsoy E, Ilyin YP, Ünlüata Ü (1996) Coastal/deep ocean interactions in the Black Sea and their ecological/environmental impacts. J Mar Syst 7:293-320

Tyler PA, Young CM (1992) Reproduction in marine inverte brates in 'stable' environments: the deep sea model. Invertebr Reprod Dev 22:185-192

Vacelet J (1969) Eponges de la roche du large et de l'étage bathyal de Méditerranée (récoltes de la soucoupe plongeante Cousteau et dragages). Mém Mus Natl Hist Nat (Sér A) 59:145-219

Vacelet J (1996) Deep-sea sponges in a Mediterranean cave In: Uiblein F, Ott J, Stachowitsch M (eds) Deep-sea and extreme shallow-water habitats: affinities and adaptations. Biosystematics and ecology Series 11. Österreichische Akademie der Wissenschaften, Wien, p 299-312

Vacelet $J$ (in press) Nouvelle signalisation d'éponges profondes en Méditerranée. Mésogée 55

This article nas submitted to the editor
Vacelet J, Boury-Esnault N (1995) Carnivorous sponges Nature 373:333-335

Vacelet J, Boury-Esnault N, Harmelin JG (1994) Hexactinellid Cave, a unique deep-sea habitat in the scuba zone. Deep Sea Res Part I Oceanogr Res Pap 41:965-973

Valentine JW, Jablonsky D (1982) Major determinants of the biogeographic pattern of the shallow-sea fauna. Bull Soc Géol Fr 24:893-899

Villora-Moreno S (1996) A new genus and species of the deep-sea family Coronarctidae (Tartigrada) from a submarine cave with deep-sea like condition. Sarsia 81 $275-283$

Vinogradova NG (1979) The geographical distribution of the abyssal and hadal (ultra-abyssal) fauna in relation to the vertical zonation of the ocean. Sarsia 64:41-50

Wulff JL (1991) Asexual fragmentation, genotype success, and population dynamics of erect branching sponges. $J$ Exp Mar Biol Ecol 149:227-247

Zabala M, Maluquer P, Harmelin JG (1993) Epibiotic bryozoans on deep-water scleractinian corals from the Catalonia slope (western Mediterranean, Spain, France). Sci Mar 57:65-78

Zabala M, Ricra T, Gili JM, Barangé M, Lobo A, Peñuelas J (1989) Water flow, trophic depletion, and benthic macrofauna impoverishment in a submarine cave from the Western Mediterranean. PSZN I: Mar Ecol 10:271-287

Manuscript first received: December 30,1996

Revised version accepted: May 5, 1997 